\title{
VARIETIES OF LIMA BEAN SHOWS DIFFERENT GROWTH RESPONSES WHEN INOCULATED WITH Bacillus sp., A PLANT GROWTH-PROMOTING BACTERIA
}

\author{
VARIEDADES DE FEIJÃO-FAVA EXIBEM DIFERENTES RESPOSTAS DE \\ CRESCIMENTO QUANDO INOCULADAS COM Bacillus $s p$., UMA BACTÉRIA \\ PROMOTORA DE CRESCIMENTO EM PLANTAS
}

\section{Evanielle Fernandes LIMA ${ }^{1}$; Vicente Paulo da COSTA NETO ${ }^{2}$; Janete Magali de ARAÚJO ${ }^{3}$; Francisco de ALCANTARA NETO ${ }^{4}$; Aurenivia BONIFACIO ${ }^{5}$; Artenisa Cerqueira RODRIGUES ${ }^{6}$}

1. Federal University of Piaui, Teresina, PI, Brazil. evanielle_fernandes@ hotmail.com; 2. Federal University of Piaui, Plant Production Post-Graduate Program, Teresina, PI, Brazil; 3. Federal University of Pernambuco, Department of Antibiotics, Recife, PE, Brazil; 4. Federal University of Piaui, Department of Plant Science, Teresina, PI, Brazil; 5. Federal University of Piaui, Department of Biology, Teresina, PI, Brazil; 6. Federal University of Piaui, Department of Agricultural Engineering and Soil Science, Teresina, PI, Brazil. artenisacerqueira@hotmail.com

\begin{abstract}
Plant growth-promoting bacteria (PGPB) comprise of soil microorganisms that cause positive effects on plant growth. The hypothesis according to which the inoculation of lima bean with PGPB Bacillus stimulates vegetative growth, which may result in a higher plant productivity, was tested. Thus, this study aimed to evaluate the effects of inoculation of two varieties of lima bean (branca and boca de moça) with Bacillus sp., UFPEDA 472 strain, based on plant growth responses. The experiment was conducted in a greenhouse using a completely randomized design. Three treatments were applied separately to each lima bean variety: the first used inoculation with Bacillus, one was submitted to nitrogen supplementation, and one was the absolute control (non-inoculated plants). The following variables were evaluated: absolute and relative growth rate, root length, stem diameter, fresh and dry mass of shoots and roots, shoot:root ratio and total chlorophyll. The results showed that lima bean displayed better growth responses when inoculated with Bacillus sp. UFPEDA 472 in relation to the treatment with nitrogen and/or non-inoculated plants. When inoculated with PGPB Bacillus, the lima bean var. branca was superior to boca de moça in terms of root length and root dry mass. The lima bean var. boca de moça inoculated with Bacillus sp. UFPEDA 472 was superior to branca in terms of absolute growth rate, stem diameter, fresh and dry mass of shoot, shoot:root ratio and total chlorophyll. In general, the lima bean var. boca de moça inoculated with Bacillus shows a better growth performance. Our results suggest that growth responses of lima bean varieties branca and boca de moça are related with a positive interaction with the PGPB Bacillus.
\end{abstract}

KEYWORDS: Phaseolus lunatus. PGPB. Absolute growth rate. Chlorophyll.

\section{INTRODUCTION}

Plant growth-promoting bacteria (PGPB) are beneficial microorganisms inhabiting the rhizosphere (FIGUEIREDO et al., 2011). They stimulate plant growth through by acting as biofertilizers and bio-stimulants, increasing the ability of the plant to resist stressful situations (GLICK, 2014; HUANG et al., 2014). PGPB act through complex mechanisms not yet fully explained (FIGUEIREDO et al., 2011; DUCA et al., 2014). PGPB may directly facilitate the supply of nutrients, produce siderophores and control phytohormone levels, particularly indole acetic acid (IAA), and consequently reduce the negative effects of environmental stress (DUCA et al., 2014; GLICK, 2014; GROBELAK et al., 2015). As indirect mechanisms, PGPB act by limiting the growth of pathogens through competitive processes (antibiosis and hyperparasitism) and the induction of systemic resistance (EGORSHINA et al., 2012; DUCA et al., 2014).

PGPB are distributed in various genera, especially Azospirillum, Bacillus, Herbaspirillum, Klebsiella and Pseudomonas (FIGUEIREDO et al., 2011). The genus Bacillus includes bacteria with a remarkable ability to synthesize a wide range of beneficial substances such as IAA, gibberellins, cytokinins, siderophores, hydrolytic enzymes and antibiotics (MUDAY et al., 2012; HUANG et al., 2014). Bacillus species have other important mechanisms promoting plant growth such as the ability to fix nitrogen and solubilize phosphate and potassium (GROBELAK et al., 2015; PII et al., 2015). Furthermore, the presence of Bacillus microbial populations stimulates the uptake of nutrients by plant roots (DUCA et al., 2014). The inoculation with Bacillus results in a significant increase in the absorption of potassium, calcium and 
magnesium by wheat roots grown in a limestone soil without fertilization (ÖĞÜT et al., 2011).

Several studies reported the efficiency of bacteria from the genus Bacillus alone or in combination with other microorganisms. Wheat seedlings treated with of $B$. subtilis spores, 11BM strain, showed a stimulating growth associated with a transient increase in IAA (EGORSHINA et al., 2012). The inoculation with $B$. siamensis, a bacterial species capable of producing and releasing gibberellins, increased the growth of banana plants (AMBAWADE; PATHADE, 2015). The MTCC 8983 strain of $B$. circulans promoted the growth of apple plants because they can solubilize phosphate and produce IAA and siderophores, and by an antagonistic activity against the fungus Dematophora mecatrix (MEHTA et al., 2010). The co-inoculation of Rhizobium phaseoli with the $\mathrm{Bx}$ strain of Bacillus sp. resulted in an increase in common bean plant growth because of an increase in nitrogen fixation, phosphorus uptake and shoot dry matter (STAJKOVIĆ et al., 2011).

Phaseolus and Vigna are major genera of leguminous plants of the family Fabaceae, with a significant importance to the world (BITOCCHI et al., 2012). The Phaseolus genus includes approximately 50 species, especially $P$. vulgaris, $P$. lunatus, $P$. dumosus, $P$. coccineus and $P$. acutifolius (SERVÍN-GARCIDUEÑAS et al., 2014). $P$. lunatus, commonly known as lima bean, is the second most important leguminous of the genre Phaseolus (BITOCCHI et al., 2012; ARAUJO et al., 2015). It is used for food and cultivated as a green manure and as cover crop (DAHMER et al., 2008). Lima bean are cultivated in several regions in Brazil. However, their cultivation is greater in the Northeast region (DAHMER et al., 2008; ARAUJO et al., 2015). Although the cultivation of lima bean has an economic and social importance, especially for family farms in the Northeast region, it presents a low yield mainly due to the lack of domesticated genotypes and a low technological level applied to its cultivation (ARAUJO et al., 2015).

Lima bean stands out as one of the most adapted leguminous crops in rainfed agriculture. However, it has low levels of productivity and a large fluctuation in production (DAHMER et al., 2008; ARAUJO et al., 2015). Despite the greater rusticity and adaptability comparing to other legumes, studies focused on the characterization of lima bean and the search for genotypes with a high productivity in different environmental conditions are still incipient (ARAUJO et al., 2015). In this context, data helping to increase the development and the productivity of lima bean are useful to increase the agronomic potential of this crop. The hypothesis according to which the inoculation of lima bean with PGPB Bacillus stimulates vegetative growth, which may result in a higher plant productivity, was tested in this study. Thus, this study aimed to evaluate the effects of inoculation of two varieties of lima bean with Bacillus sp. UFPEDA 472 on the growth of plants in a greenhouse.

\section{MATERIAL AND METHODS}

\section{Preparation of the inoculant}

The Bacillus sp. UFPEDA 472 was kindly supplied from the Microorganisms Culture Collection UFPEDA maintained by Department of Antibiotics of the Federal University of Pernambuco (Recife, Pernambuco state, Brazil). The strain UFPEDA 472 of Bacillus sp. was purified and multiplied in Petri dishes containing a Trypticase soy agar (TSA) solid medium. For the preparation of the inoculant, the Bacillus sp. UFPEDA 472 was collected in Erlenmeyer flasks with a Trypticase soy broth (TSB) liquid medium and incubated in a rotator shaker $(220 \mathrm{rpm})$ at $28^{\circ} \mathrm{C}$ for $96 \mathrm{~h}$.

\section{Conduction of the experiment}

The experiment was conducted in a greenhouse $\left(5^{\circ} 5^{\prime} 21^{\prime \prime} \mathrm{S}\right.$ and $\left.42^{\circ} 48^{\prime} 07^{\prime \prime} \mathrm{W}\right)$ at the Department of Crop Science in Federal University of Piaui (Teresina, Piaui state, Brazil). During the experiment, the temperature varied between 21 and $35^{\circ} \mathrm{C}$. The relative humidity, total annual insolation and the photoperiod were $65 \%, 2,625$ hours and $12 \mathrm{~h}$, respectively. Initially, seeds of lima bean var. boca de moça and branca were disinfected by immersing seeds into $70 \%$ alcohol (45 s) and $2.5 \%$ sodium hypochlorite $(60 \mathrm{~s})$, followed by nine washes with sterile distilled water (HUNGRIA; ARAÚJO, 1994). Prior to filling the pots, the soil was autoclaved $\left(120^{\circ} \mathrm{C}, 101 \mathrm{kPa}, 1 \mathrm{~h}\right)$ and subjected to supplementation with phosphorus pentoxide and potassium oxide following the recommendations by Lopes et al. (2010) and the results of soil chemical analysis (Table 1).

Seeds of lima bean previously disinfected were sown in pots containing sieved and sterile soil as substrate $\left(3.5 \mathrm{~kg} \mathrm{pot}{ }^{-1}\right)$, and simultaneously inoculated with $1.0 \mathrm{~mL}$ of TSB liquid medium containing the Bacillus sp. UFPEDA 472 at

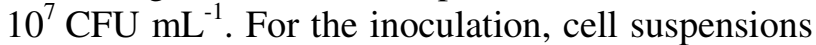
of Bacillus sp. (UFPEDA 472 strain) in TSB liquid medium were previously adjusted at $10^{7} \mathrm{CFU} \mathrm{\textrm {mL } ^ { - 1 }}$ in a spectrophotometer at $560 \mathrm{~nm}$. The thinning was carried out at seven days and two seedlings were 
kept in each pot (an experimental unit). For the treatment with nitrogen, a nitrogen supplementation with ammonium sulfate $\left(0.07 \mathrm{~g}\right.$ pot $\left.^{-1}\right)$ was performed at 7,14 and 21 days after thinning following recommendations of soil chemical analysis. Non-inoculated plants were considered as the absolute control.

Table 1. Chemical analysis of the soil used in the experiment.

\begin{tabular}{|c|c|c|c|c|c|c|c|c|}
\hline $\begin{array}{c}\mathbf{p H} \\
\left(\mathbf{H}_{2} \mathrm{O}\right)\end{array}$ & $\begin{array}{c}P \\
\left(\mathrm{mg} \mathrm{dm}^{-3}\right)\end{array}$ & $\mathbf{K}^{+}$ & $\mathrm{Na}^{+}$ & $\mathrm{Ca}^{+2}$ & $\underset{\left(\mathrm{cmol}_{\mathrm{c}} \mathrm{dm}^{-3}\right)}{\mathrm{Mg}^{+3}}$ & $\mathbf{H}^{+}$ & CEC & SB \\
\hline 6.8 & 1.50 & 19.70 & 12.30 & 1.90 & 0.50 & 1.50 & 3.98 & 2.48 \\
\hline
\end{tabular}

During the experimental period, lima bean plants were watered every day until field capacity with distilled water and every two days with the nitrogen-free Hoagland \& Arnon (1950) nutritive solution modified by Silveira et al. (1998) $(7.0 \mathrm{~mL}$ $\left.\operatorname{pot}^{-1}\right)$. The height of lima bean plants was evaluated every five days and the data were used to calculate absolute growth rate (BENINCASA, 2003). At harvest (45 days), root length, stem diameter and fresh mass of shoots and roots were evaluated. Total chlorophyll was determined using the Clorofilog ${ }^{\circledR}$ (Falker, Brazil). The dry mass of the shoots and roots was determined after drying in a forced-air ventilation oven at $65{ }^{\circ} \mathrm{C}$ until constant weight. The mass of shoots and roots were used to calculate the shoot:root ratio, whereas total dry mass was used to calculate relative growth rate (BENINCASA, 2003).

\section{Experimental design and statistical analysis}

The experimental design was completely randomized. Three treatments were applied separately to each lima bean variety (branca and boca de moça): one was inoculated with Bacillus, one was submitted to nitrogen supplementation, and one was the absolute control (non-inoculated plants). It were used four replications. Data obtained were tested for normality using a Shapiro-Wilk test $(P<0.05)$. The variables were subjected to analysis of variance (ANOVA) with an F test $(P<0.05)$. The comparison of means was performed using a Tukey's test $(P<0.05)$. All analyses described were performed with the ASSISTAT ${ }^{\circledR}$ statistical software (SILVA, 2012).

\section{RESULTS}

The varieties of lima bean had different responses to the inoculation with Bacillus sp., UFPEDA 472 strain, compared with the treatments with nitrogen and without inoculation (Figure 1). The variety boca de moça had a growth rate higher than the variety branca in all treatments (Figure 1A). Comparing with non-inoculated plants, lima bean inoculated with Bacillus sp. UFPEDA 472 showed a growth rate higher than $177 \%$ and $111 \%$ for lima bean var. branca and boca de moça, respectively. Non-inoculated lima bean, varieties branca and boca de moça, had an absolute growth rate lower than $60 \%$ and 47\%, respectively, compared with nitrogen-supplied plants (Figure 1A). When lima bean var. branca and boca de moça grown in a soil with nitrogen (nitrogen-supplied plants) were compared to plants inoculated with Bacillus sp. UFPEDA 472 , it was possible to note that the absolute growth rate was lower in nitrogen-supplied plants regarding both lima bean varieties.

Non-inoculated lima bean var. branca and boca de moça had a lower relative growth rate in relation to other treatments (Figure 1B). The relative growth rate of lima bean var. branca and boca de moça inoculated with Bacillus sp. UFPEDA 472 was higher than non-inoculated lima bean plants by approximately $40 \%$ (Figure 1B). Also regarding non-inoculated plants, lima bean varieties grown in a soil with nitrogen (nitrogen-supplied plants) increased by $18 \%$ and $22 \%$ the relative growth rate for branca and boca de moça varieties, respectively. An increase of $15 \%$ in relative growth rate was recorded for the lima bean var. branca when inoculated with Bacillus sp. UFPEDA 472 in relation to plants grown in a soil with nitrogen (nitrogen-supplied plants). For the lima bean var. boca de moça, this increase was less expressive (approximately 10\%) (Figure 1B).

There were no significant differences in root length between lima bean varieties of noninoculated plants (Figure 2A). As shown in figure $2 \mathrm{~A}$, the lima bean var. branca had a greater root length than boca de moça when fertilized with nitrogen (34\% superior) or inoculated with Bacillus sp. UFPEDA 472 (16\% higher). Noninoculated lima bean, var. branca, had a root length $36 \%$ smaller when compared to nitrogen-supplied plants. For the lima bean var. boca de moça, no significant differences were recorded (Figure 2A). 

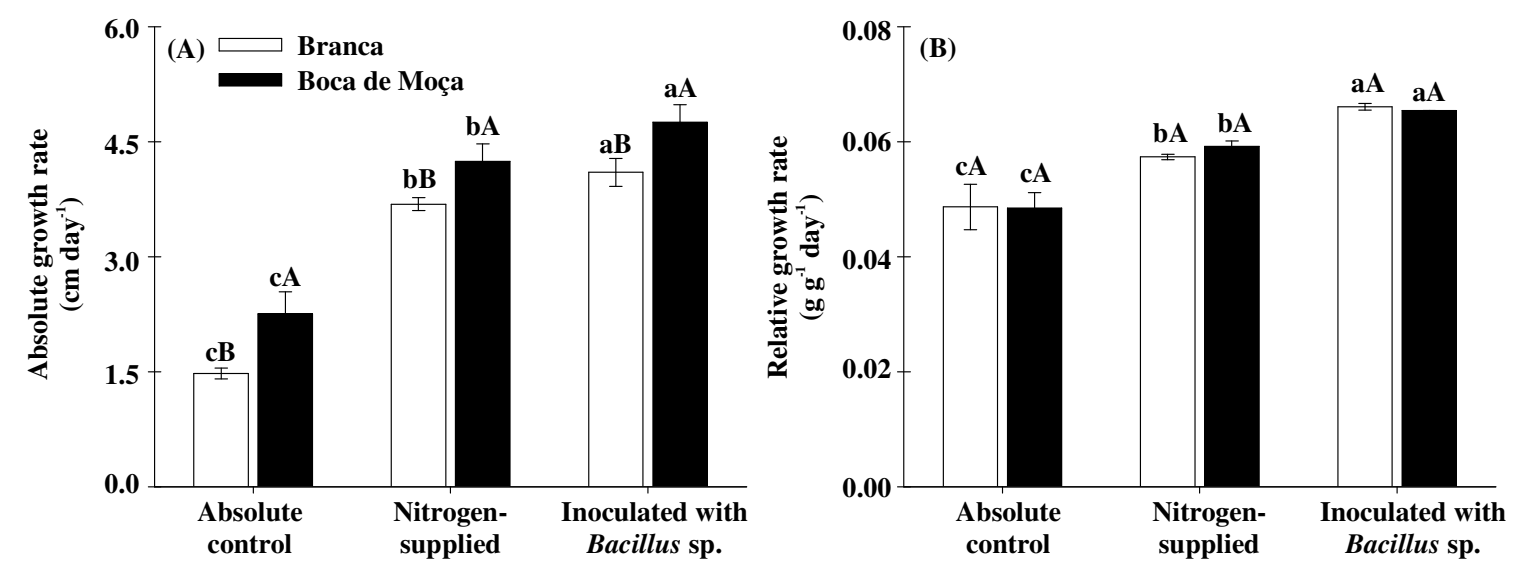

Figure 1. Growth parameters of lima bean var. branca and boca de moça supplied with nitrogen or inoculated with Bacillus sp. UFPEDA 472: (A) absolute growth rate and (B) relative growth rate. Absolute control plants are non-inoculated plants cultivated without nitrogen supplementation. Different lowercase letters represent significant differences among treatments in each variety, while different uppercase letters indicate significant differences between the two varieties by Tukey's test $(P<0.05)$.
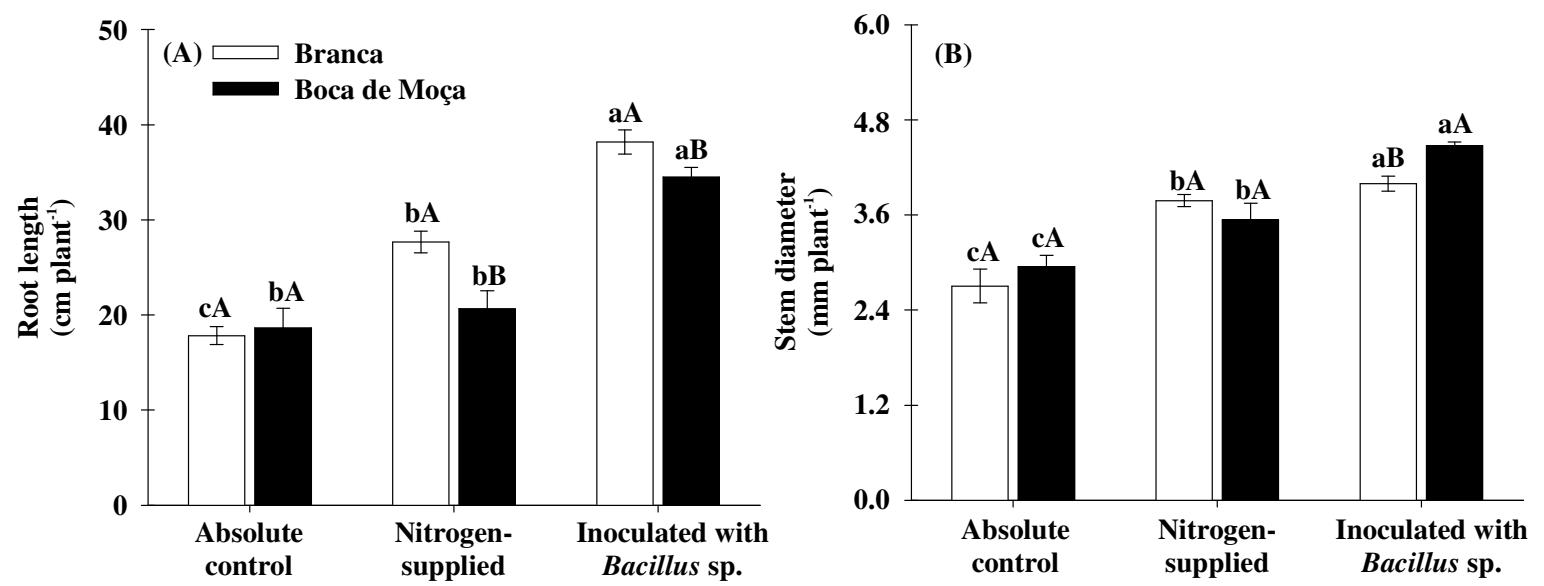

Figure 2. Root length (A) and stem diameter (B) of the lima bean var. branca and boca de moça supplied with nitrogen or inoculated with Bacillus sp. UFPEDA 472. Absolute control plants are non-inoculated plants cultivated without nitrogen supplementation. Different lowercase letters represent significant differences among treatments for each variety, while different uppercase letters indicate significant differences between the two varieties by Tukey's test $(P<0.05)$.

The varieties branca and boca de moça inoculated with Bacillus sp. UFPEDA 472 showed an increase in root length of approximately $120 \%$ and $80 \%$ when compared to non-inoculated plants, respectively (Figure $2 \mathrm{~A}$ ). In addition, an expressive increase in root length $(60 \%)$ was observed for lima bean varieties inoculated with Bacillus sp. UFPEDA 472 compared to lima bean varieties fertilized with nitrogen.

There were no significant differences between lima bean varieties regarding stem diameter in a same treatment. However, significant differences among the different treatments were observed (Figure 2). As shown in figure 2B, the stem diameter of lima bean plants inoculated with
Bacillus sp. UFPEDA 472 was superior to the others treatments. A higher increase of $45 \%$ in stem diameter was observed for lima bean var. branca and boca de moça inoculated with Bacillus sp. UFPEDA 472 in relation to non-inoculated plants (Figure 2B). Lima bean plants grown in a soil with nitrogen (nitrogen-supplied plants) had $40 \%$ and $20 \%$ increases in stem diameter for the varieties branca and boca de moça, respectively, compared to non-inoculated plants. Lima bean inoculated with Bacillus sp. UFPEDA 472 had a higher stem diameter in relation to nitrogen-supplied lima bean plants, mainly the lima bean var. boca de moça, which had increases of approximately $30 \%$. 

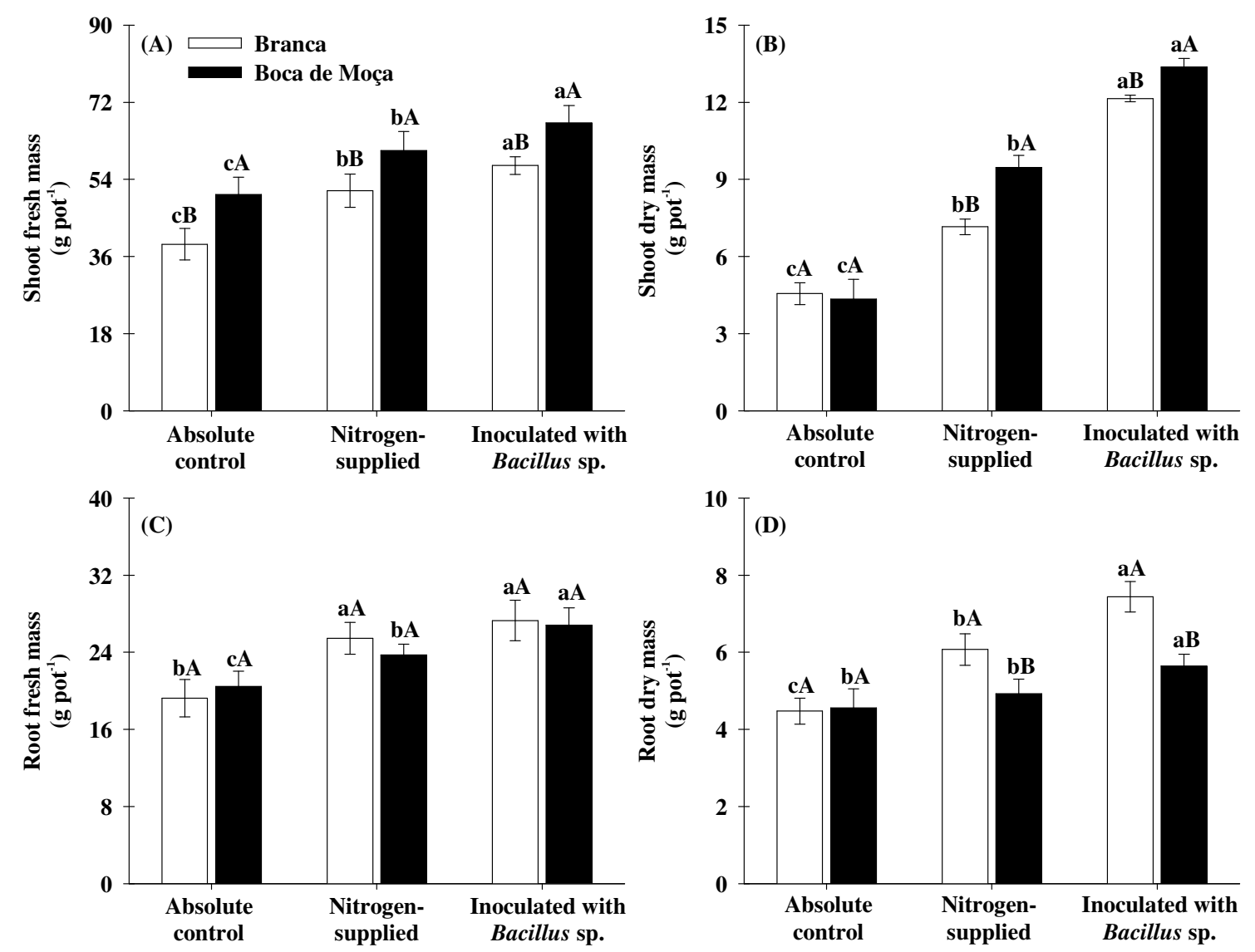

Figure 3. Shoot and root fresh (A, C) and dry (B, D) mass of lima bean var. branca and boca de moça supplied with nitrogen or inoculated with Bacillus sp. UFPEDA 472. Absolute control plants are noninoculated plants cultivated without nitrogen supplementation. Different lowercase letters represent significant differences among treatments for each variety, while different uppercase letters indicate significant differences between the two varieties by Tukey's test $(P<0.05)$.

The fresh and dry mass of shoots and roots increased in the two lima bean varieties inoculated with Bacillus sp. UFPEDA 472 (Figure 3). The shoot fresh mass increased in lima bean, especially the lima bean var. boca de moça, which stood out in all treatments (Figure 3A). The lima bean var. boca de moça inoculated with Bacillus sp. UFPEDA 472 showed an increase in fresh mass of shoots of approximately $10 \%$ compared to nitrogen-supplied plants, and $47 \%$ compared to the absolute control (non-inoculated plants). There was an increase of approximately $20 \%$ in the shoot fresh mass of lima bean var. boca de moça in relation to the lima bean var. branca when inoculated with Bacillus sp. UFPEDA 472 or when nitrogen-supplied lima bean plants (Figure 3A). Additionally, lima bean var. branca and boca de moça inoculated with Bacillus sp. UFPEDA 472 had $42 \%$ and $31 \%$ increases, respectively, in root fresh mass compared to noninoculated plants (Figure 3B).

Changes in the dry mass of shoots and roots were recorded for lima bean varieties inoculated with Bacillus sp. UFPEDA 472, mainly the shoot dry mass of the lima bean var. boca de moça (Figure 3C and 3D). Lima bean var. boca de moça inoculated with Bacillus sp. UFPEDA 472 had an increase in shoot dry mass of $208 \%$ and $41 \%$ compared to non-inoculated plants and nitrogensupplied plants, respectively (Figure 3C). As shown in the Figure 3D, lima bean var. branca has a root dry mass $23 \%$ and $32 \%$ higher than boca de moça grown in a soil with nitrogen or when inoculated with Bacillus sp. UFPEDA 472, respectively. In relation to non-inoculated plants, an increase of $66 \%$ in root dry mass was observed for the lima bean var. branca inoculated with Bacillus sp. UFPEDA 472 (Figure 3D). Lima bean var. branca inoculated with Bacillus sp. UFPEDA 472, compared to nitrogensupplied plants, had a $23 \%$ increase in root dry mass.

Shoot and root dry weight of all treatments were compared with non-inoculated lima bean plants and data are shown as percentages in the Figure 4 . There was an increase in the percentage of 
shoot and root dry weight of the lima bean var. branca and boca de moça, mainly when lima bean varieties were inoculated with Bacillus sp. UFPEDA 472. The increase in shoot dry weight in lima bean var. branca inoculated with Bacillus sp. UFPEDA 472 was $183 \%$, while lima bean var. boca de moça had increases higher than $231 \%$ (Figure 4). There was a significant difference regarding shoot dry weight when lima bean varieties were grown in a soil with nitrogen. The lima bean var. boca de moça was higher than lima bean var. branca by approximately $60 \%$ regarding shoot dry weight. Regarding root dry weight, the lima bean var. branca was higher than the lima bean var. boca de moça when fertilized with nitrogen or inoculated with Bacillus sp. UFPEDA 472. Due to the inoculation with Bacillus sp. UFPEDA 472, lima bean var. branca had increases higher than $65 \%$ in root dry weight when compared to non-inoculated plants.

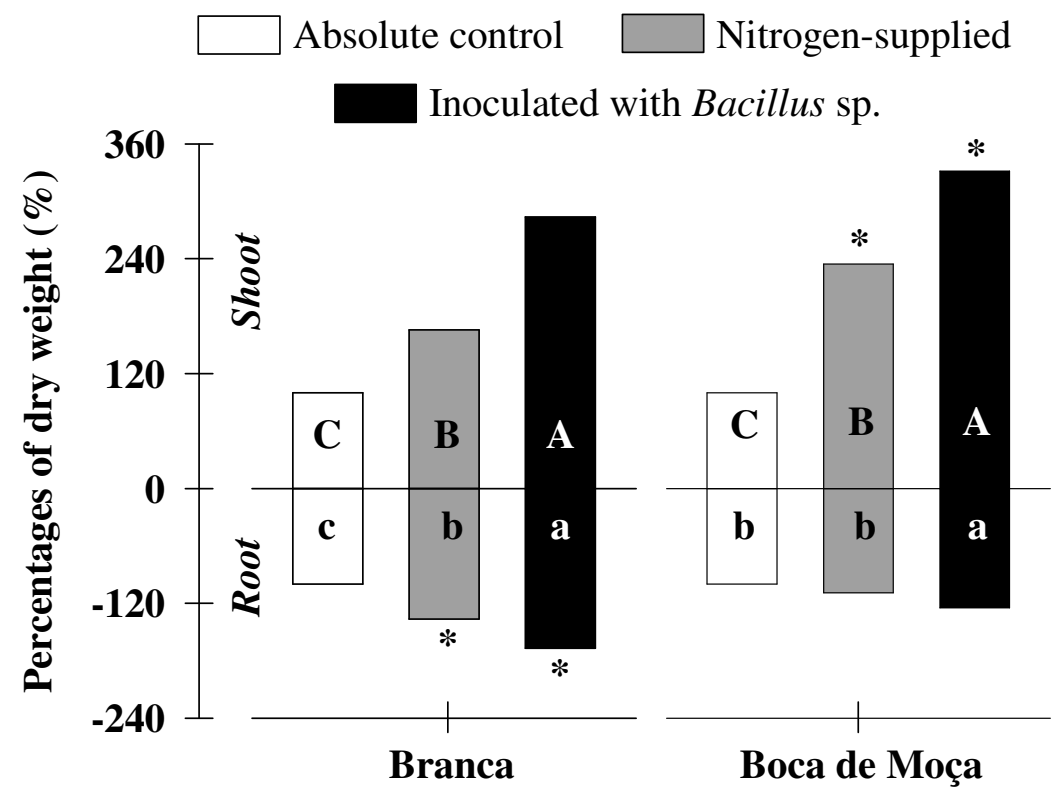

Figure 4. Distribution of dry weight between shoots and roots of lima bean var. branca and boca de moça supplied with nitrogen or inoculated with Bacillus sp. UFPEDA 472. Absolute control plants are non-inoculated plants cultivated without nitrogen supplementation. Means followed by the same lowercase (shoot) or uppercase (root) letters do not differ statistically $(P<0.05)$ among treatments with each variety. The asterisk $(*)$ indicates significant differences between the two varieties by Tukey's test $(P<0.05)$.

Significant differences between the shoot:root ratio of the two lima bean varieties were recorded for plants supplied with nitrogen and plants inoculated with Bacillus sp. UFPEDA 472 (Figure 5). A maximum value of shoot:root ratio $\left(2.38 \mathrm{~g} \mathrm{~g}^{-1}\right)$ was recorded for the lima bean var. boca de moça inoculated with Bacillus sp. UFPEDA 472 (Figure 5). Lima bean var. boca de moça was $55 \%$ and $45 \%$ superior than the lima bean var. branca when cultivated with nitrogen in a nutritive solution and when inoculated with Bacillus sp. UFPEDA 472, respectively. As illustrated in Figure 5, the shoot:root ratio of lima bean var. branca and boca de moça inoculated with Bacillus sp. UFPEDA 472 increased by $62 \%$ and $203 \%$ compared to noninoculated plants, respectively. It is possible to note that lima bean var. branca and boca de moça increase by $38 \%$ and $30 \%$ the shoot:root ratio when inoculated with Bacillus sp. UFPEDA 472 in relation to nitrogen-supplied plants (Figure 5). 


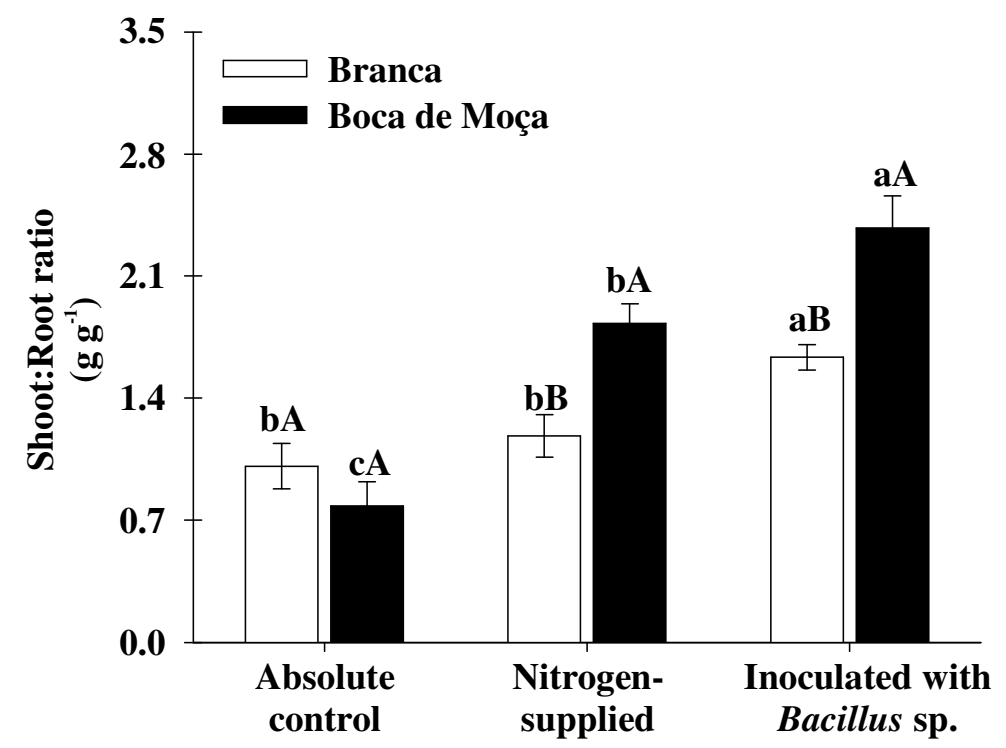

Figure 5. Shoot:root ratio of lima bean var. branca and boca de moça supplied with nitrogen or inoculated with Bacillus sp. UFPEDA 472. Absolute control plants are non-inoculated plants cultivated without nitrogen supplementation. Different lowercase letters represent significant differences among treatments for each variety, while different uppercase letters indicate significant differences between the two varieties by Tukey's test $(P<0.05)$.

The total chlorophyll was measured in both lima bean varieties submitted to different treatments. Significant differences were recorded (Figure 6). As shown in Figure 6, the lima bean var. boca de moça was superior than the lima bean var. branca when inoculated with Bacillus sp. UFPEDA 472 or when supplied with nitrogen. Compared to non-inoculated plants, the lima bean var. boca de moça inoculated with Bacillus sp. UFPEDA 472 stood out in relation to the lima bean var. branca. Increases of $62 \%$ for total chlorophyll were recorded (Figure 6). Lima bean varieties grown in a soil with nitrogen (nitrogen-supplied plants) shows increases in total chlorophyll of $26 \%$ and $36 \%$ for the varieties branca and boca de moça, respectively, in relation to non-inoculated plants. An increase higher than $15 \%$ in total chlorophyll was recorded for lima bean var. branca and boca de moça when inoculated with Bacillus sp. UFPEDA 472 in relation to plants grown in a soil with nitrogen (nitrogen-supplied plants).

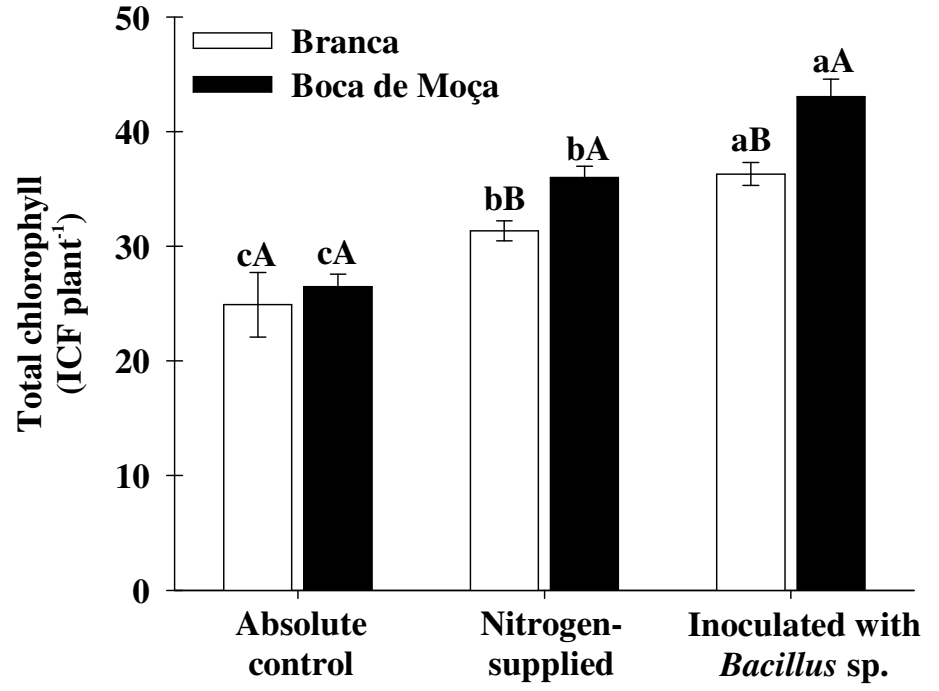

Figure 6. Total chlorophyll of lima bean var. branca and boca de moça supplied with nitrogen or inoculated with Bacillus sp. UFPEDA 472. Absolute control plants are non-inoculated plants cultivated without nitrogen supplementation. Different lowercase letters represent significant differences among treatments for each variety. Different uppercase letters indicate significant differences between the two varieties by Tukey's test $(P<0.05)$. 


\section{DISCUSSION}

This study evaluated the inoculation of lima bean, varieties branca and boca de moça, with Bacillus sp., UFPEDA 472 strain, on parameters related to plant growth and development. Bacillus are considered plant growth-promoting bacteria (PGPB) and, jointly with Pseudomonas and Azospirillum, are the most studied group of PGPB in the world (DUCA et al., 2014; GROBELAK et al., 2015). This genus comprises of species with plant growth-promoting characteristics occupying the rhizosphere of many plant species. It provides beneficial effects to the host plant (FIGUEIREDO et al., 2011; HUANG et al., 2014). In general, the varieties of lima bean studied herein increase plant growth parameters when inoculated with Bacillus sp. UFPEDA 472. The promotion of plant growth by PGPB Bacillus involves a large number of mechanisms, such as nitrogen fixation, mineralization of nutrients, production of siderophores and hormones such as auxins and gibberellins (HUANG et al., 2014; PII et al., 2015).

The absolute growth rate was calculated based on the plant height of lima bean, and therefore is strongly related to photosynthesis. According to Lopez et al. (2012), bacterial endophytes, such as some Bacillus strains, may increase the photosynthetic activity. Lima bean plants inoculated with Bacillus sp. UFPEDA 472, mainly the lima bean var. boca de moça (Figure 1A), were capable of growing in a nitrogen-free medium. These results confirmed that Bacillus sp. UFPEDA are capable of fixing nitrogen and therefore promoting plant growth, as observed by $\mathrm{Xu}$ et al. (2014) upon studying the plant growth-promoting activity of $B$. subtilis HYT-12-1 on tomato seedlings. If nitrogen influences the structure and the composition of the photosynthetic apparatus (ANDREWS; LEA, 2013), its absence may result in a decreased photosynthetic rate and therefore in less plant growth, as observed for the absolute control.

When inoculated with Bacillus sp. UFPEDA 472 , the lima bean var. branca was superior than lima bean var. boca de moça in terms of root length and root dry mass (Figure 2A and 3B). According to Figueiredo et al. (2011), the growth-promoting ability of some bacteria may be highly specific to certain plant species, varieties, cultivars and genotypes. This is probably the reason why PGPB Bacillus sp. UFPEDA 472 effectively interacted with the lima bean var. branca, resulting in the promotion of root development. The increase in root length of groundnut inoculated with $B$. licheniformis MML2501 was associated with production of IAA
(PRASHANTH; MATHIVANAN, 2010). In wheat treated with spores of $B$. subtilis $11 \mathrm{BM}$, a stimulation to growth was observed associated with a transient increase in IAA (EGORSHINA et al., 2012). IAA is the most commonly phytohormone studied worldwide. It belongs to the auxin group, which acts mainly on the formation of lateral roots and root hair cells (MUDAY et al., 2012; HUANG et al., 2014).

Bacterial isolates that produces IAA, when inoculated in mung bean (Vigna radiata), increase their shoot length and stem diameter (MATSUOKA et al., 2015). Similarly, it was reported in this study increases in stem diameter for the lima bean var. boca de moça inoculated with Bacillus sp. UFPEDA 472. This is probably because the growth response of this plant is related with a synergistic interaction between IAA and 1-aminocyclopropane1-carboxylate (ACC) deaminase (MUDAY et al., 2012; MATSUOKA et al., 2015). ACC is a direct ethylene precursor, and ACC deaminase metabolizes ACC reducing the volume of ethylene (PII et al., 2015). Ethylene in low concentrations facilitates plant growth, whereas high ethylene concentrations cause suppression of growth (HUANG et al., 2014). Glick (2014) stresses that PGPB secreting IAA and producing ACC deaminase may efficiently promote plant growth due to the action of IAA simultaneously with the control of an excessive ethylene production.

IAA, abscisic acid, gibberellin, cytokinins and ethylene are growth regulators produced by PGPB acting in shoots and roots, increasing the intake of nutrients by plants (HUANG et al., 2014). For example, Bacillus megaterium promoted the growth of Arabidopsis thaliana and this response requires an intact cytokinin-signaling pathway (ORTÍZ-CASTRO et al., 2008). The authors reported that the bacterial inoculation caused a threefold increase in shoot fresh mass in wild-type A. thaliana (Col-0 and C-24 ecotypes) in relation to non-inoculated plants. In this study, lima bean inoculated with Bacillus sp. UFPEDA 472 increased the fresh and dry mass of shoots, mainly the lima bean var. boca de moça (Figure 3 and 5). Similar findings were recorded for shoot dry mass of rice plants inoculated with Bacillus sp. SVPR30 (BENEDUZI et al., 2008), quailbush inoculated with $B$. pumilus ES4 or RIZO1 grown in a soil with mine tailings (DE-BASHAN et al., 2010), and Brachypodium inoculated with B. subtilis B26 (GAGNÉ-BOURQUE et al., 2015).

The inoculation of lima bean with Bacillus sp. UFPEDA 472 resulted in a significant increase in shoot:root ratio. When inoculated with Bacillus 
sp. UFPEDA 472, the lima bean var. boca de moça achieved the maximum value of shoot:root ratio in relation to the other treatments. Shoot:root ratio increased by $20 \%$ in red pepper under salt stress when inoculated with $B$. aryabhattai RS341, which is an ACC deaminase-producing halotolerant bacterium (SIDDIKEE et al., 2012). Furthermore, the inoculation of teak with $B$. subtilis KED-4 and the co-inoculation simultaneously with B. subtilis KED-4 and Pseudomonas fluorescens TCO-6, two bacteria with a phosphate-solubilizing capacity, increased the shoot:root ratio probably because of increases in the phosphate availability in the soil solution (MOHAN; RADHAKRISHNAN, 2012). In general, the change in the shoot:root ratio is an adaptive response to changes in the nutrient availability (PÉRET et al., 2011; MOHAN; RADHAKRISHNAN, 2012).

An increase in shoot:root ratio is expected when plants show adequate amounts of nutrients in their tissues, especially nitrogen and phosphate (PÉRET et al., 2011; SIDDIKEE et al., 2012). Nitrogen is an essential nutrient strongly related with chlorophyll, a pigment found in plants and vital for photosynthesis (HOHMANN-MARRIOTT; BLANKENSHIP, 2011). The data presented in Figure 6 show that the inoculation of lima bean with Bacillus sp. UFPEDA 472 results in a significant increase in total chlorophyll. Similar results were recorded for radish inoculated with B. subtilis (MOHAMED; GOMAA, 2012), for potato inoculated with $B$. cereus (DAWWAM et al., 2013) and for mustard inoculated with $B$. megaterium mj1212, a soil microorganism able to solubilize phosphate (KANG et al., 2014). In addition, Stefan et al. (2013) observed that B. pummilus or $B$. mycoides increased chlorophyll levels of runner bean ( $P$. coccineus), a specie closely related to lima bean.
An adequate plant-bacteria interaction may trigger an increase in the synthesis of chlorophyll and thus lead to an increase in photosynthesis (KANG et al., 2014). Thereby, the flow of photoassimilates may be directed to the growth of shoots, aiming develop more leaf areas photosynthetically active. In consequence, the shoot:root ratio increases. This is probably due to the presence of Bacillus sp. UFPEDA 472 in the rhizosphere of lima bean, especially in the lima bean var. boca de moça. This stimulates the photosynthetic process and a more efficient absorption of nutrients (MOHAMED; GOMAA, 2012; DAWWAM et al., 2013). This statement is based on the strong increase in total chlorophyll shown by the lima bean var. boca de moça when inoculated with Bacillus sp. UFPEDA 472 in relation to non-inoculated plants. In addition, the lima bean var. boca de moça inoculated with Bacillus sp. UFPEDA 472 has a higher shoot dry mass and shoot:root ratio compared to the other treatments.

\section{CONCLUSION}

The increase in plant growth of the lima bean var. boca de moça, when inoculated by PGPB Bacillus, is the consequence of a positive and adequate interaction between this variety of lima bean and the strain UFPEDA 472 of Bacillus sp. However, further studies are needed to explain what are the additional characteristics and/or factors involved in the promotion of plant growth induced by PGPB Bacillus.

\section{ACKNOWLEDGMENTS}

We would like to acknowledge the National Council of Technological and Scientific Development $(\mathrm{CNPq})$ that supported this work.

RESUMO: Bactérias promotoras de crescimento em plantas (BPCP) compreendem microrganismos do solo que causam efeitos positivos no crescimento vegetal. A hipótese de que a inoculação de feijão-fava com BPCP Bacillus estimula o crescimento vegetativo, o qual pode resultar em uma maior produtividade vegetal, foi testado. Assim, este estudo objetivou avaliar o efeito da inoculação de duas variedades de feijão-fava (branca e boca de moça) com Bacillus sp., estirpe UFPEDA 472, baseado em respostas de crescimento vegetal. O experimento foi conduzido em casa de vegetação usando um delineamento completamente ao acaso. Três tratamentos foram aplicados separadamente à cada variedade de feijão-fava: o primeiro utilizou a inoculação com Bacillus sp. UFPEDA 472, um foi submetido à suplementação com nitrogênio e um foi o controle absoluto (plantas não inoculadas). As seguintes variáveis foram avaliadas: taxa de crescimento absoluto e relativo, comprimento das raízes, diâmetro do caule, massa fresca e seca da parte aérea e raízes, relação parte aérea:raiz e clorofila total. Os resultados mostram que o feijão-fava exibiu melhores respostas de crescimento quando inoculadas com Bacillus sp. UFPEDA 472 em relação ao tratamento com nitrogênio e/ou às plantas não inoculadas. Quando inoculado com Bacillus sp. UFPEDA 472, o feijão-fava var. branca foi superior à boca de moça em termos de comprimento e massa seca das raízes. O feijão-fava var. boca de moça inoculado com Bacillus sp. UFPEDA 472 foi superior à branca na taxa de crescimento absoluto, diâmetro do caule, massa fresca e seca da parte aérea, relação 
parte aérea:raiz e clorofila total. No geral, o feijão-fava var. boca de moça inoculado com Bacillus sp. UFPEDA 472 mostrou melhor performance de crescimento. Nossos resultados sugerem que as respostas de crescimento das variedades de feijão-fava branca e boca de moça são relacionadas com uma interação positiva com o Bacillus sp. UFPEDA 472.

PALAVRAS-CHAVE: Phaseolus lunatus. BPCP. Taxa de crescimento absoluto. Clorofila.

\section{REFERENCES}

ARAUJO, A. S. F.; LOPES, Â. C. A.; GOMES, R. L. F.; BESERRA JUNIOR, J. E. A.; ANTUNES, J. E. L.; FIGUEIREDO, M. V. B. Diversity of native rhizobia-nodulating Phaseolus lunatus in Brazil. Legume Research, India, v. 38, n. 5, p. 653-657, 2015. http://www.arccjournals.com/uploads/articles/17653657LR237.pdf

AMBAWADE, M. S.; PATHADE, G. R. Production of gibberellic acid by Bacillus siamensis BE 76 isolated from banana plant (Musa spp.). International Journal of Science and Research, India, v. 4, p. 394-398, 2015. http://www.ijsr.net/archive/v4i7/SUB152006.pdf

ANDREWS, M.; LEA, P. J. Our nitrogen 'footprint': the need for increased crop nitrogen use efficiency. Annals of Applied Biology, Warwick, v. 163, p. 165-169, 2013. http://dx.doi.org/10.1111/aab.12052

BENEDUZI, A.; PERES, D.; VARGAS, L. K.; BODANESE-ZANETTINI, M. H.; PASSAGLIA, L. M. P. Evaluation of genetic diversity and plant growth promoting activities of nitrogen-fixing bacilli isolated from rice fields in South Brazil. Applied Soil Ecology, United Kingdom, v. 39, p. 311-320, 2008. http://dx.doi.org/10.1016/j.apsoil.2008.01.006

BENINCASA, M. M. P. Análise de crescimento de plantas: noções básicas. Jaboticabal: FUNEP, 2003. 41 p.

BITOCCHI, E.; NANNI, L.; BELLUCCI, E.; ROSSI, M.; GIARDINI, A.; ZEULI, P. S.; LOGOZZO, G.; STOUGAARD, J.; MCCLEAN, P.; ATTENE, G.; PAPA, R. Mesoamerican origin of the common bean (Phaseolus vulgaris L.) is revealed by sequence data. Proceedings of the National Academy of Sciences, Washington, v. 109, p. E788-E796, 2012. http://dx.doi.org/10.1073/pnas.1108973109

DAHMER, N.; CONTERATO, I. F.; SCHIFINO-WITTMANN, M. T. Considerations on the enigmatic and controversial Phaseolus-Vigna complex and their economically important species. Current Agricultural Science and Technology, Pelotas, v. 14, p. 8-18, 2008. http://dx.doi.org/10.18539/cast.v14i4.1950

DAWWAM, G. E.; ELBELTAGY, A.; EMARA, H. M.; ABBAS, I. H.; HASSAN, M. M. Beneficial effect of plant growth promoting bacteria isolated from the roots of potato plant. Annals of Agricultural Sciences, Cairo, v. 58, p. 195-201, 2013. http://dx.doi.org/10.1016/j.aoas.2013.07.007

DE-BASHAN, L. E.; HERNANDEZ, J. P.; BASHAN, Y.; MAIER, R. M. Bacillus pumilus ES4: candidate plant growth-promoting bacterium to enhance establishment of plants in mine tailings. Environmental and Experimental Botany, Finland, v. 69, p. 343-352, 2010. http://dx.doi.org/10.1016/j.envexpbot.2010.04.014

DUCA, D.; LORV, J.; PATTEN, C. L.; ROSE, D.; GLICK, B. R. Indole-3-acetic acid in plant-microbe interactions. Antonie Van Leeuwenhoek, United Kingdom, v. 106, p. 85-125, 2014. http://dx.doi.org/10.1016/10.1007/s10482-013-0095-y

EGORSHINA, A. A.; KHAIRULLIN, R. M.; SAKHABUTDINOVA, A. R.; LUK'YANTSEV, M. A. Involvement of phytohormones in the development of interaction between wheat seedlings and endophytic Bacillus subtilis strain 11BM. Russian Journal of Plant Physiology, Russian, v. 59, p. 134-140, 2012. http://dx.doi.org/10.1134/S1021443711050062 
FIGUEIREDO, M. V. B.; SELDIN, L.; ARAUJO, F. F.; MARIANO, R. L. R. Plant growth promoting rhizobacteria: fundamentals and applications. In: MAHESHWARI, D. K. (Ed.), Plant growth and health promoting bacteria. Berlin: Springer Heidelberg, 2011. p. 21-43.

GAGNÉ-BOURQUE, F.; MAYER, B. F.; CHARRON, J. B.; VALI, H.; BERTRAND, A.; JABAJI, S. Accelerated growth rate and increased drought stress resilience of the model grass Brachypodium distachyon colonized by Bacillus subtilis B26. PloS One, USA, v. 10, p. e0130456, 2015.

http://dx.doi.org/10.1371/journal.pone.0130456

GLICK, B.R. Bacteria with ACC deaminase can promote plant growth and help to feed the world.

Microbiological Research, USA, v. 169, p. 30-39, 2014. http://dx.doi.org/10.1016/j.micres.2013.09.009

GROBELAK, A.; NAPORA, A.; KACPRZAK, M. Using plant growth-promoting rhizobacteria (PGPR) to improve plant growth. Ecological Engineering, USA, v. 84, p. 22-28, 2015.

http://dx.doi.org/10.1016/j.ecoleng.2015.07.019

HOAGLAND, D.; ARNON, D. I. The water culture method for growing plants without soil. California: Agriculture Experimental Station Circular, 1950. 250 p.

HOHMANN-MARRIOTT, M. F.; BLANKENSHIP, R. E. Evolution of photosynthesis. Annual Review of Plant Biology, USA, v. 62, p. 515-548, 2011. http://dx.doi.org/10.1146/annurev-arplant-042110-103811

HUANG, X. F.; CHAPARRO, J. M.; REARDON, K. F.; ZHANG, R.; SHEN, Q.; VIVANCO, J. M. Rhizosphere interactions: root exudates, microbes, and microbial communities. Botany, Canadian, v. 92, p. 267-275, 2014. http://dx.doi.org/10.1139/cjb-2013-0225

HUNGRIA, M.; ARAÚJO, R. S. Manual de métodos empregados em estudos de microbiologia agrícola. Brasília: EMBRAPA, 1994. 59 p.

KANG, S. M.; RADHAKRISHNAN, R.; YOU, Y. H.; JOO, G. J.; LEE, I. J.; LEE, K. E.; KIM, J. H. Phosphate solubilizing Bacillus megaterium mj1212 regulates endogenous plant carbohydrates and amino acids contents to promote mustard plant growth. Indian Journal of Microbiology, India, v. 54, p. 427-433, 2014. http://dx.doi.org/10.1007/s12088-014-0476-6

LOPES, A. C. A.; GOMES, R. L. F.; ARAÚJO, A. S. F. A cultura do feijão-fava no Meio-norte do Brasil. Teresina: EDUFPI, 2010. 272 p.

LOPEZ, B. R.; TINOCO-OJANGUREN, C.; BACILIO, M.; MENDOZA, A.; BASHAN, Y. Endophytic bacteria of the rock-dwelling cactus Mammillaria fraileana affect plant growth and mobilization of elements from rocks. Environmental and Experimental Botany, Finland, v. 81, p. 26-36, 2012. http://dx.doi.org/10.1016/j.envexpbot.2012.02.014

MATSUOKA, H.; OHWAKI, Y.; TERAKADO-TONOOKA, J.; TANAKA, F. Changes in volatiles in carrots inoculated with ACC deaminase-producing bacteria isolated from organic crops. Plant and Soil, Australia, v. 396, p. 1-14, 2015. http://dx.doi.org/10.1007/s11104-015-2769-x

MEHTA, P.; CHAUHAN, A.; MAHAJAN, R.; MAHAJAN, P. K.; SHIRKOT, C. K. Strain of Bacillus circulans isolated from apple rhizosphere showing plant growth promoting potential. Current Science, India, v. 98, p. 538-542, 2010. http://www.currentscience.ac.in/Downloads/article_id_098_04_0538_0542_0.pdf

MOHAMED, H. I.; GOMAA, E. Z. Effect of plant growth promoting Bacillus subtilis and Pseudomonas fluorescens on growth and pigment composition of radish plants (Raphanus sativus) under $\mathrm{NaCl}$ stress. Photosynthetica, USA, v. 50, p. 263-272, 2012. http://dx.doi.org/10.1007/s11099-012-0032-8 
MOHAN, V.; RADHAKRISHNAN, A. Screening of phosphate solubilizing bacterial isolates for growth improvement of Tectona grandis Linn. Research Journal of Microbiology, USA, v. 7, p. 101-113, 2012. http://docsdrive.com/pdfs/academicjournals/jm/0000/40253-40253.pdf

MUDAY, G. K.; RAHMAN, A.; BINDER, B. M. Auxin and ethylene: collaborators or competitors? Trends in Plant Science, Cambridge, v. 17, p. 181-195, 2012. http://dx.doi.org/10.1016/j.tplants.2012.02.001

ÖĞÜT, M.; ER, F.; NEUMANN, G. Increased proton extrusion of wheat roots by inoculation with phosphorus solubilizing microorganism. Plant and Soil, Australia, v. 339, p. 285-297, 2011.

http://dx.doi.org/10.1007/s11104-010-0578-9

ORTÍZ-CASTRO, R.; VALENCIA-CANTERO, E.; LÓPEZ-BUCIO, J. Plant growth promotion by Bacillus megaterium involves cytokinin signaling. Plant, Signaling \& Behavior, Cambridge, v. 3, p. 263-265, 2008. http://www.ncbi.nlm.nih.gov/pmc/articles/PMC2634197/pdf/psb0304_0263.pdf

PÉRET, B.; CLÉMENT, M.; NUSSAUME, L.; DESNOS, T. Root developmental adaptation to phosphate starvation: better safe than sorry. Trends in Plant Science, Cambridge, v. 16, p. 442-450, 2011. http://dx.doi.org/10.1016/j.tplants.2011.05.006

PII, Y.; MIMMO, T.; TOMASI, N.; TERZANO, R.; CESCO, S.; CRECCHIO, C. Microbial interactions in the rhizosphere: beneficial influences of plant growth-promoting rhizobacteria on nutrient acquisition process: a review. Biology and Fertility of Soils, Italy, v. 51, p. 403-415, 2015. http://dx.doi.org/10.1007/s00374-0150996-1

PRASHANTH, S.; MATHIVANAN, N. Growth promotion of groundnut by IAA producing rhizobacteria Bacillus licheniformis MML2501. Archives of Phytopathology and Plant Protection, United Kingdom, v. 43, p. 191-208, 2010. http://dx.doi.org/10.1080/03235400802404734

SERVÍN-GARCIDUEÑAS, L. E.; ZAYAS-DEL MORAL, A.; ORMEÑO-ORRILLO, E.; ROGEL, M. A.; DELGADO-SALINAS, A.; SÁNCHEZ, F.; MARTÍNEZ-ROMERO, E. Symbiont shift towards Rhizobium nodulation in a group of phylogenetically related Phaseolus species. Molecular Phylogenetics and Evolution, USA, v. 79, p. 1-11, 2014. http://dx.doi.org/10.1016/j.ympev.2014.06.006

SIDDIKEE, M. A.; CHAUHAN, P. S.; SA, T. Regulation of ethylene biosynthesis under salt stress in red pepper (Capsicum annuum L.) by 1-aminocyclopropane-1-carboxylic acid (ACC) deaminase-producing halotolerant bacteria. Journal of Plant Growth Regulation, United Kingdom, v. 31, p. 265-272, 2012. http://dx.doi.org/10.1007/s00344-011-9236-6

SILVA, F. A. S. Assistência Estatística - ASSISTAT (7.6 beta). Campina Grande: Departamento de Engenharia Agrícola - Universidade Federal de Campina Grande, 2012. Disponível em: http://www.assistat.com/

SILVEIRA, J. A. G.; CONTADO, J.; RODRIGUES, J.; OLIVEIRA, J. Phosphoenolpyruvate carboxylase and glutamine synthetase activities in relation to nitrogen fixation in cowpea nodules. Brazilian Journal of Plant Physiology, São Paulo, v. 10, p. 19-23, 1998. http://www.cnpdia.embrapa.br/rbfv/pdfs/v10n1p19

STAJKOVIĆ, O.; DELIĆ, D.; JOŠIĆ, D.; KUZMANOVIĆ, Đ.; RASULIĆ, N.; KNEŽEVIĆ-VUKČEVIĆ, J. Improvement of common bean growth by co-inoculation with Rhizobium and plant growth-promoting bacteria. Romanian Biotechnological Letters, Romania, v. 16, p. 5919-5926, 2011.

http://www.rombio.eu/rbl1vol16/11\%20Stajkovic.pdf

STEFAN, M.; MUNTEANU, N.; STOLERU, V.; MIHASAN, M.; HRITCU, L. Seed inoculation with plant growth promoting rhizobacteria enhances photosynthesis and yield of runner bean (Phaseolus coccineus L.). Scientia Horticulturae, United Kingdom, v. 151, p. 22-29. 2013. http://dx.doi.org/10.1016/j.scienta.2012.12.006 
XU, M.; SHENG, J.; CHEN, L.; MEN, Y.; GAN, L.; GUO, S.; SHEN, L. Bacterial community compositions of tomato (Lycopersicum esculentum Mill.) seeds and plant growth promoting activity of ACC deaminase producing Bacillus subtilis (HYT-12-1) on tomato seedlings. World Journal of Microbiology and Biotechnology, India, v. 30, p. 835-845, 2014. http://dx.doi.org/10.1007/s11274-013-1486-y 